\title{
Generator Dosing Unit
}

National Cancer Institute

\section{Source}

National Cancer Institute. Generator Dosing Unit. NCI Thesaurus. Code C48496.

A dosing unit equal to the amount of active ing redient(s) produced by a generator. 